\title{
O gênero Portulaca L. (Portulacaceae) no Brasil ${ }^{1}$
}

\author{
Alexa Araujo de Oliveira Paes Coelho ${ }^{2,4}$ e Ana Maria Giulietti ${ }^{3}$
}

Recebido em 14/08/2008. Aceito em 14/02/2010

RESUMO - (O gênero Portulaca L. (Portulacaceae) no Brasil). O gênero Portulaca tem distribuição principalmente pantropical, com algumas espécies ocorrendo em áreas subtropicais das Américas e África e poucas espécies na Austrália, Ásia e Europa. Portulaca inclui plantas herbáceas, com folhas geralmente alternas, portando na axila tricomas muito ou pouco desenvolvidos e flores com duas sépalas, 4-5 pétalas livres, estames numerosos e ovário ínfero. No Brasil foram reconhecidas 13 espécies, com distribuição da Amazônia até o Sul do país, mas as maiores populações estão concentradas na região semi-árida. Para cada espécie é apresentada descrição morfológica, comentários e ilustrações.

Palavras-chave: Levantamento florístico, descrições, ilustrações, espécies brasileiras

ABSTRACT - (The genus Portulaca L. (Portulacaceae) in Brazil). The genus Portulaca has a mainly pantropical distribution, while some African and New World species are subtropical and a few occur in Australia, Europe and Asia. Portulaca is composed of herbs usually with alternate leaves, bearing long, usually conspicuous, axillary trichomes, and with flowers composed of 2 sepals and 4-5 petals free at the base, numerous stamens and an inferior ovary. In Brazil 13 species are recognized and each taxa is characterized morphologically, with taxonomic notes and illustrations.

Key words: Floristic inventory, descriptions, illustrations, Brazilian species

\section{Introdução}

Portulacaceae inclui cerca de 30 gêneros e 500 espécies, que se distribuem principalmente no Oeste da América do Norte, América do Sul e África, com alguns poucos representantes na Europa e Ásia. Os gêneros mais representativos são: Portulaca L. com cerca de 100 espécies, Calandrinia Kunth com cerca de 150 espécies e Talinum Adans com mais de 50 espécies Carolin (1993). Para o Brasil, Rohrbach (1872) na "Flora Brasiliensis" refere dez espécies em dois gêneros: Talinum e Portulaca, esse último com oito espécies.

O gênero Portulaca inclui plantas herbáceas, carnosas, anuais ou perenes, com folhas alternas, inflorescência em cimeira, 2 sépalas, 4-5 pétalas livres, estames geralmente numerosos, ovário ínfero e fruto cápsula com deiscência longitudinal ou transversal. É amplamente distribuído nos Neotrópicos e regiões tropicais e subtropicais da África, ocorrendo também algumas poucas espécies na Austrália, Europa e Ásia.

A estimativa do número de espécies de Portulaca varia de acordo com vários autores: desde 40 em Geesink (1969) a mais de 100 em Legrand (1958) ou 200 em Willis (1966). Trabalhos mais recentes como Carolin (1993) e Eggli \& Ford-Werntz (2002) reconhecem aproximadamente 115 espécies. Toda esta variação no número de espécies está associada à grande variabilidade morfológica do gênero. $\mathrm{O}$ trabalho mais amplo feito para o gênero foi o de Legrand (1962) que reconheceu 62 espécies para as Américas, sendo que destas, 21 eram referidas para o Brasil. Apesar dessa variação morfológica ao nível das espécies, o gênero como um todo é de fácil reconhecimento em relação aos outros da família, e considerado monofilético nas recentes análises filogenéticas moleculares como em Applequist \& Wallace (2001).
Poucos estudos referentes à família Portulacaceae e em especial ao gênero Portulaca têm sido feitos no Brasil. A base taxonômica para o gênero no país ainda é o tratamento realizado por Rohrbach (1872) para a Flora Brasiliensis, reconhecendo oito espécies. Posteriormente vários levantamentos regionais foram feitos podendo ser citados os trabalhos de Teixeira (1959) para a cidade do Rio de Janeiro; Mattos (1961) para o município de São Joaquim (RS); Lima \& Lima (1968) para o estado de Pernambuco; Rodrigues \& Furlan (2002) para o estado de São Paulo e Coelho \& Giulietti (2006), para a Bahia. Coelho et al. (in press) como parte da revisão das espécies neotropicais do gênero Portulaca apresentaram 20 sinonimizacoes, três lectótipos, um neótipo e um epitipo.

O presente trabalho tem como objetivo apresentar o levantamento das espécies do gênero de ocorrência no Brasil, através da identificação dos espécimes depositados em vários herbários e coletas em vários estados brasileiros.

\section{Material e métodos}

Foram realizadas coletas de Portulaca nos estados da Bahia, Espírito Santo, Mato Grosso, Minas Gerais, Pernambuco, Piauí, São Paulo e Sergipe. Cerca de $60 \%$ das espécies estudadas foram coletadas, fotografadas em campo e as flores colocadas em álcool a $70 \%$ para posterior análise morfológica. O material coletado foi depositado no herbário HUEFS. Foram também analisadas as coleções de Portulaca depositadas nos seguintes herbários: ALCB, ASE, B, BA, BHCB, BM, CAS, CEN, CEPEC, CESJ, CH, CRI, CTES, CVRD, E, ESA, F, GUA, HB, HBR, HEPH, HRB, HRCB, HUFU, HXBH, IAC, IAN, ICN, INPA, JPB, K, LP, MBM, MBML, MG, NY, P, PACA, PEL, RB, RFA, RUSU, SF, SI, SJRP, SMDB, SP, SPF, UB, UEC e UPCB, acrônimos segundo Holmgren et al. (2006). O trabalho taxonômico nas diversas etapas seguiu o procedimento proposto por Mori et al. (1989).

No item Material Examinado, para as espécies com ampla distribuição foi selecionado um material representativo por Estado e para aquelas de distribuição restrita, até três espécimes, incluindo os materiais-tipos analisados.

\footnotetext{
Parte da tese de Doutorado da primeira Autora

2 Universidade do Estado da Bahia, Departamento de Ciências Exatas e da Terra, Alagoinhas, BA, Brasil; Universidade Estadual de Feira de Santana, Departamento de Ciências Biológicas, Programa de Pós-Graduação em Botânica, Feira de Santana, BA, Brasil

3 Universidade Estadual de Feira de Santana, Departamento de Ciências Biológicas, Programa de Pós-Graduação em Botânica, Feira de Santana, BA, Brasil

4 Autor para correspondência: alexapaescoelho@gmail.com
} 


\section{Resultados e discussão}

Caracterização e distribuição do gênero no Brasil - As espécies de Portulaca são ervas suculentas, perenes ou anuais. As raízes são tuberosas, cujo eixo principal é alongado e bastante espessado, de onde partem raízes secundárias mais finas. Em P. werdermannii a raiz principal mede de $5-10 \mathrm{~cm}$ de comprimento.

Os caules são aéreos, cilíndricos, bastante ramificados desde a base, com ramificação do tipo simpodial como em P. oleracea ou monopodial como em P. elatior. Podem ser prostrados e sarmentosos, como em $P$. hirsutissima ou eretos atingindo até $80 \mathrm{~cm}$ como em $P$. elatior. São caules herbáceos e suculentos, porém em $P$. minensis ocorre espessamento lignificado da base até a porção mediana do caule principal, mas os ramos laterais são herbáceos. Os caules são verdes, porém em algumas espécies, como por exemplo, $P$. umbraticola podem apresentar coloração avermelhada. Em $P$. frieseana ocorre caule subterrâneo globoso, do tipo cormo. Essa espécie ocorre em área de cerrado, onde esse tipo de sistema subterrâneo ocorre em espécies de diversas famílias.

Os nós caulinares além das folhas também produzem os tricomas axilares. Em algumas espécies como P. elatior as folhas mais velhas são geralmente caducas, permanecendo no caule apenas a cicatriz da inserção das mesmas e os tricomas, o que dá ao caule uma aparência lanosa, embora os entrenós sejam sempre glabros. Nas espécies brasileiras, os tricomas variam em cor, localização, tamanho, densidade e organização celular. Foram observados desde tricomas brancos como em $P$. werdermannii até castanhoamarelados em $P$. elatior e cinza-escuros em $P$. minensis. Os tricomas podem ser exclusivamente interaxilares como em $P$. oleracea ou ocorrerem ao redor de todo o nó como em P. mucronata. Podem ser mais ou menos do tamanho das folhas, bem maiores ou bem menores. Geralmente as espécies que possuem tricomas maiores que as folhas, esses são muito abundantes e praticamente recobrem todo o caule. Diferentemente, as espécies que possuem tricomas menores que as folhas, esses são restritos à região nodal. Em P. oleracea os tricomas são muito pequenos, tornandose quase imperceptíveis a olho nu. A organização celular dos tricomas observado ao microscópio óptico, possibilitou a sua classificação em três tipos, que estão de acordo com os encontrados por Prabhakar (1975) para as espécies da Índia: I-Multisseriado: $\mathrm{O}$ tricoma é multicelular, formado por 3-4 células em espessura na região mediana, mais espesso na base, formado por um número maior de séries de células e afilado para o ápice, geralmente terminado por 1-2 células. A parede é geralmente lisa, mas em P. mucronata é ligeiramente estriada. II-Multisseriado com cabeça capitada: observado em P. umbraticola e P.oleracea. O tricoma é clavado, com cavidade central, multicelular e multisseriado. III - Escama: observado em Portulaca minensis. É uma estrutura alongada, afilada e achatada, formada por várias séries de células com paredes bem espessas e lúmen estreito. Os tricomas axilares mostraram-se importantes na separação das espécies.

Portulaca apresenta dois tipos de folhas: as caulinares que ocorrem ao longo do caule e podem ser caducas ou não e as folhas involucrais que estão ao redor da inflorescência e geralmente são permanentes. As folhas caulinares são simples, alternas, suculentas, verdes, podendo ser subsésseis (pecíolos 0,3-0,5 mm) ou pecioladas (pecíolos 0,5-1,0 mm). A margem é inteira podendo apresentar bordos esbranquiçados, formados apenas pela epiderme. O limbo tem forma variada desde linear até obovado, espatulado, lanceolado, oblongo-lanceolado a oblongo-linear. A base é cuneada a subarredondada e o ápice pode ser agudo, acuminado, mucronado, arredondado ou emarginado. Todas as espécies brasileiras têm folhas, glabras, exceto $P$. hirsutissima que possui pequenos tricomas unicelulares e glandulares e tricomas tectores distribuídos em todo o limbo, sendo mais abundantes nas margens e na face adaxial e são pouco visíveis a olho nu. A face adaxial do limbo foliar é geralmente convexa, enquanto que a face abaxial pode ter nervura central evidente ou não, ou possuir uma pequena depressão central só visível ao microscópio e que ocorre desde a base até o ápice do limbo foliar como em $P$. werdermannii ou da base até a porção mediana do limbo foliar como em $P$. halimoides. As folhas podem ser caducas como em $P$. elatior ou persistentes como em P. mucronata. As folhas involucrais, apresentam as mesmas características morfológicas das folhas caulinares, porém variam em número de uma espécie para a outra, sendo geralmente entre 4-10 por inflorescência. Carolin (1987) denomina estas folhas como brácteas das cimeiras.

As flores são actinomorfas, sésseis, bissexuadas e de diâmetro variável, havendo espécies com flores pequenas (2-4 $\mathrm{mm}$ ) e com flores grandes até $40 \mathrm{~mm}$ em $P$. werdermannii. São efêmeras, ocorrendo normalmente a antese de uma só flor de cada vez. No Brasil as flores desse gênero se abrem entre 10-12 h da manhã e permanecem abertas até 14-16h, daí o nome popular de "onze horas". O cálice é formado por duas sépalas de cor verde, com textura herbácea, conadas na base, com margem inteira e ápice agudo a acuminado. Geralmente são glabras, porém em $P$. hirsutissima ocorrem pequenos tricomas glandulares ou tectores, semelhantes aos das folhas. As sépalas têm a face dorsal convexa, mas em P. oleracea $\mathrm{o}$ dorso carenado é importante na identificação da espécie. As sépalas são persistentes na frutificação e junto com as pétalas formam uma espécie de cone que protege o desenvolvimento do fruto, caindo geralmente após a maturação do mesmo. A corola é constituída por cinco ou raramente quatro pétalas, de pré-floração imbricada. Em indivíduos cultivados de $P$. grandiflora é observada a duplicação da corola que pode conter vários verticilos de pétalas. As pétalas podem ser de cor amarela, branca, rosa ou magenta, podendo existir cores matizadas. Em populações naturais de $P$. mucronata foram encontrados indivíduos com pétalas amarelas matizadas de rosa. A cor da pétala é constante em algumas espécies como em $P$. werdermannii de cor magenta e $P$. minensis de cor 
amarela. Porém algumas espécies podem apresentar variação na coloração das pétalas como em $P$. halimoides que varia de amarela a branca e $P$. hirsutissima que varia de rosa a amarela. As pétalas são obovais de ápices emarginados, são delicadas, deliqüescentes, e adnatas à base das sépalas e do tubo estaminal.

$\mathrm{O}$ androceu é polistêmone, variando de seis estames em $P$. halimoides a numerosos em $P$. werdermannii. Os estames são unidos na base e adnatos à base da corola, formando uma estrutura que foi denominada para Montia e Grahamia por Carolin (1987) como arco andro-corolínico e que é sempre atravessado pelo estilete. Os filetes são filiformes, cilíndricos, de cor amarelada e glabros, exceto em $P$. oleracea que apresenta pequenos tricomas na base. As anteras são bitecas, de cor amarela, com deiscência longitudinal. Os grãos de pólen têm aberturas ruguladas com diferentes tamanhos de raios, a escultura é espinhosa e a endoexina é muito fina ou aparentemente ausente.

O gineceu é sincárpico, com cinco a sete carpelos. O ovário é semi-ínfero a ínfero com hipanto de natureza apendicular, unilocular com placentação axilar passando a central livre ou basal. Geesink (1969) refere que em Portulaca os carpelos são inicialmente unidos pelo septo e a placentação é axilar. Porém, durante o desenvolvimento, os septos são perdidos e então a placentação axilar passa a ser interpretada como central livre. Os estiletes são unidos na base, formando uma coluna que varia de tamanho de acordo com a espécie e os ramos estigmáticos variam em número, de quatro como em $P$. halimoides a sete como em $P$. werdermannii.

$O$ fruto é uma cápsula com deiscência transversal, podendo ser definido como um pixídio originado de ovário ínfero. $\mathrm{O}$ fruto incluindo o ovário e o hipanto tem a forma obovóide e o opérculo (tampa) tem forma que varia desde globular até hemisférico ou cônico. A deiscência pode ocorrer em várias alturas na cápsula, sendo as sementes liberadas quando o opérculo cai embora algumas sementes ainda possam permanecer na parte basal da cápsula. Em P. umbraticola o fruto é bastante distinto das demais espécies do gênero por apresentar uma ala membranácea ao redor do bordo superior do pixídio. Os pixídios podem ser sésseis como em $P$. werdermannii, subsésseis como em $P$. elatior ou com pedicelo desenvolvido como em $P$. halimoides.

As sementes em Portulaca são geralmente numerosas por pixídio, variando entre $10 \mathrm{em}$ P. minensis a $35 \mathrm{em}$ P. mucronata. São pequenas $(0,3-0,8 \mathrm{~mm})$, reniformes e geralmente não apresentam arilo. As sementes que apresentam arilo (como em P. oleracea) esse é sempre derivado do funículo. A reserva da semente é um perisperma duro que circunda o embrião recurvado. As sementes imaturas são de coloração negra ou cinza passando a castanhas quando maduras. A superfície pode ter brilho como em $P$. umbraticola ou serem opacas como em $P$. werdermannii. A escultura das sementes apresenta grande variação nas espécies, incluindo desde sementes lisas como em $P$. mucronata até papilosa, ou tuberculada como em P. umbraticola.

O gênero Portulaca L. é amplamente distribuído nos neotrópicos e regiões tropicais e subtropicais da África, ocorrendo também algumas poucas espécies na Austrália, Europa e Ásia. No Brasil, o gênero inclui 13 espécies e uma ampla distribuição, ocorrendo em todas as regiões, porém com maior concentração e diversidade nas regiões Nordeste e Sudeste, especialmente nos estados da Bahia, Minas Gerais, Rio de Janeiro e São Paulo. As espécies são encontradas nos mais variados ambientes, especialmente em áreas abertas, campos arenosos e solos pedregosos do campo rupestre. Várias delas são ruderais e algumas consideradas quase cosmopolitas como P. oleracea L.

Chave para identificação das espécies do gênero Portulaca

1. Folha com limbo achatado oblanceolado, oblongo-lanceolado a espatulado.

2. Limbo oblongo-lanceolado 5-20 x 1-8 mm; tricomas axilares conspícuos, pouco abundantes, multisseriados, circundando todo o nó.

3. Caule prostrado ou semi-prostrado, ramos com estrias horizontais, folhas 5-15 x 1-2 mm; pedicelo do fruto cerca de $1 \mathrm{~mm}$ compr 1. P. amilis

3. Caule ereto, ramos sem estrias horizontais, folhas $15-20$ x 4-8 mm; fruto séssil

\section{P. mucronata}

2. Limbo oblanceolado a espatulado 10-35 x 5-15 mm; tricomas axilares inconspícuos, pouco abundantes, multisseriados com cabeça captada, interaxilares.

4. Fruto sem ala membranácea; botão floral com sépalas carenadas, carena aliforme.

10. P. oleracea

4. Fruto com ala membranácea; botão floral com sépalas não carenadas

12. P. umbraticola

1. Folha com limbo cilíndrico a semi-cilíndrico, linear-lanceolado a oblongo-linear, raramente achatado.

5. Folhas e sépalas providas de tricomas curtos (glandulares e tectores), tricomas axilares muito conspícuos, brancos, às vezes cobrindo todos os ramos e folhas. 7. P. hirsutissima

5. Folhas e sépalas glabras; tricomas axilares conspícuos ou não.

6. Caule ereto com base lignificada; tricomas axilares escariosos, castanho escuros 8. P. minensis 
6. Caule ereto ou prostrado, base nunca lignificada; tricomas axilares multisseriados, brancos a castanho-claros.

7. Caule ereto 20-80 cm alt. folhas caducas, ao longo do caule, permanecendo apenas os tricomas axilares de cor esbranquiçada a amarelada; flores amarelas .

7. Caule prostrado; folhas persistentes, ao longo do caule, tricomas axilares de cor branca a castanho; flores de cores variadas do amarelo a púrpura.

8. Flores 4-8mm diâm., pétalas 4-5 de cor amarelo, branco ou rosa, até 12 estames, fruto com pedicelo maior que $1 \mathrm{~mm}$ comp. 5. $P$. halimoides

8. Flores 15-20 mm diâm. pétalas 5, geralmente de cor magenta ou púrpura, mais de 12 estames, fruto séssil ou com pedicelo menor que $1 \mathrm{~mm}$ comp.

9. Raiz principal tuberosa com porção superior obovóide e porção inferior afilada, pecíolo $0,5-1,5 \mathrm{~mm}$.

3. P. frieseana

9. Raiz principal tuberosa e alongada, folhas sésseis ou pecíolo menor que $0,5 \mathrm{~mm}$.

10. Folhas com ápice mucronado, pétalas $1,5-2 \mathrm{~cm}$ de comprimento, endêmica da Chapada Diamantina na Bahia. 13. P. werdermannii

10. Folhas com ápice agudo a acuminado; pétalas $0,4-1,5 \mathrm{~cm}$ de comprimento

11. Tricomas axilares multisseriados, conspícuos, densos, circundando todo o nó; endêmica dos cerrados do Paraná.

6. P. hatschbachii

11. Tricomas axilares multisseriados, conspícuos a inconspícuos, interaxilares

12. Flores com 0,4-0,8 cm de diam.; tricomas axilares conspícuos

11. P. pilosa

12. Flores com 2,0-5,0 cm de diam.; tricomas axilares inconspícuos 4. $P$. grandiflora

1. Portulaca amilis Spegazzini, An. Soc. Cient. Argentina 92 (104): 6. 1921. Tipo: Paraguai, Assuncion, 10.1919, Spegazzini s.n. (Holótipo: MVM!)

Fig. 1-3

Erva com caule prostrado, ramos 4-8 cm compr., verde, com pequenas estrias horizontais, pouco ramificado, tricomas axilares 3-5 mm compr., multisseriado, pouco abundantes, circundando todo o nó, conspícuos, lanosos, castanhos. Folhas pecioladas 2-4 mm, cilíndrico; limbo 5-15 x 1-2 mm, oblongo-lanceolado, achatado, nervura central evidente; base arredondada; ápice agudo a acuminado; margem inteira sem bordo esbranquiçado; glabras; persistentes; folhas involucrais 6-8 por inflorescência, 6-10 x 1-2 mm, oblongo-lanceoladas; base arredondada; ápices agudos a acuminados; margem inteira sem bordo esbranquiçado; glabras. Inflorescência 1-3 flores. Flores sésseis; sépalas 4-6 mm compr., glabras, dorso côncavo, ápices agudos; pétalas 5, rosas; lâmina obcordada 6-8 x 2-3 mm, ápices emarginados; estames 10-20; filetes 1-2 mm compr.; anteras 1-1,5 mm compr.; estilete 2-4,5 mm compr.; ramos estigmáticos 4-5, ca. $2 \mathrm{~mm}$ compr. Pixídio 4-5 mm compr., pedicelado, pedicelo ca. $1 \mathrm{~mm}$ compr., opérculo hemisférico ca. $2 \mathrm{~mm}$ alt. Sementes 15-20 por fruto, negras, lisas, opacas, 0,6-0,8 $\mathrm{mm}$.

Material selecionado: BRASIL: Mato Grosso: Poconé, 06/XII/1991, fl.fr., Schesse 2480 (CH). Mato Grosso do Sul: Bela Vista, 18/V/1988, fl.fr., Bertolotto et al. 554 (COR). Pará: Sete Varas, 05/VIII/1981, fr., Strudwick et al. 4132 (MG). Paraná: Igassú, 20/I/1949, fl. fr., Schwarz, 7253 (RB). Rio de Janeiro: Rio de Janeiro, 21/XII/1982, fl. fr., Casari et al. 908 (GUA). Santa Catarina: Itajaí, 16-I-1966, fr. Klein 6502, 6770 (CRI). São Paulo: Bertioga, 15/X/1999, fl. fr., Magenta et al. 222 (HRCB).
A presença de estrias nos ramos, dispostas horizontalmente em relação ao ápice da planta é uma característica que permite reconhecer Portulaca amilis facilmente. Além das estrias, Portulaca amilis tem hábito, flor e folhas de tamanhos reduzidos em relação a Portulaca mucronata. Apesar disto, espécimes da espécie são muitas vezes identificados como $P$. mucronata, que também possui ornamentação da semente lisa.

A cor da pétala em Portulaca amilis também é um caráter bastante discutido. Legrand $(1953,1962)$ referiu que as populações do Norte do Uruguai apresentam pétalas de cores amarelo e rosa. Os exemplares examinados do Brasil mostraram a ocorrência de indivíduos apenas com pétalas rosa.

2. Portulaca elatior Mart. ex Rohrb. In: Mart. Fl. bras. 14 (2): 302. t.69. 1872. Tipo: Brasil, Bahia: Juazeiro, nas margens do São Francisco, s.d., Martius 2336 (holótipo: $\mathrm{M}$, foto!)

Fig. 4-7

Erva 20-80 cm alt., caule ereto, verde, ramificado desde a base, tricomas axilares ca. $5 \mathrm{~mm}$ compr., multisseriados, circundando todo o nó, abundantes, lanosos, esbranquiçados a amarelados. Folhas com pecíolo 1,5-2 $\mathrm{mm}$, achatado, castanho no material seco; limbo 10-25 x 0,5-1 mm, linear-lanceolado, plano, com pequena nervura central proeminente na face adaxial; base arredondada; ápice obtuso a agudo, algumas vezes mucronado; margem inteira sem bordo esbranquiçado; glabras, geralmente caducas; folhas involucrais 5-10 por inflorescência, 10-14 x 0,6-1 $\mathrm{mm}$, lineares-lanceoladas; base arredondada; ápice obtuso a agudo; margem inteira sem bordo esbranquiçado; glabras. Inflorescência 3-8 flores, com uma flor abrindo de cada vez. Flores sésseis; sépalas 4-7 mm compr., glabras, com algumas estrias avermelhadas, dorso côncavo, ápices agudos; pétalas 


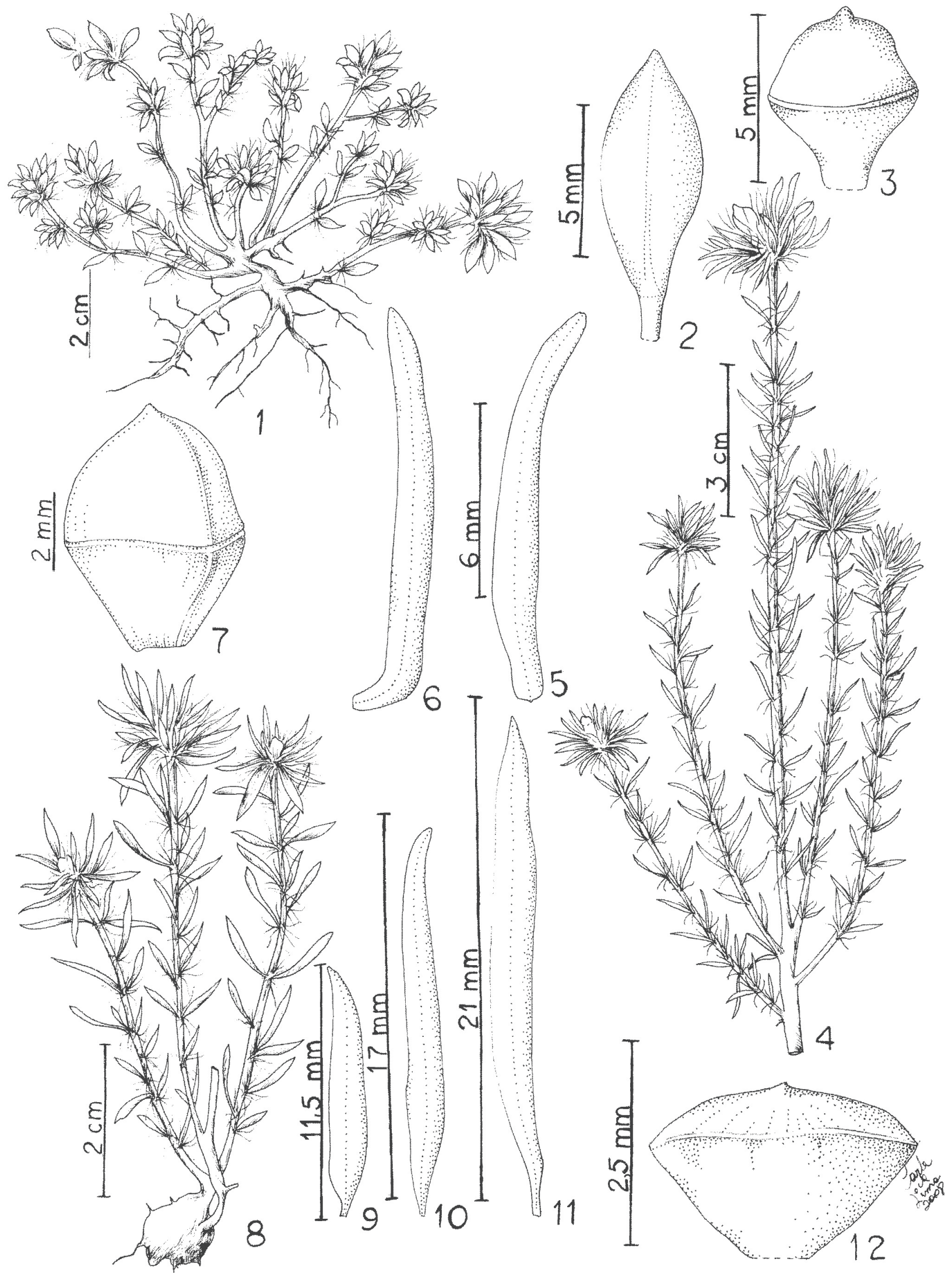

Figuras 1-12. Portulaca amilis Speg. 1. Hábito; 2. Folha; 3. Pixídio (Hatschbach 49172); Portulaca elatior Mart. 4. Hábito; 5-6. Folhas; 7. Pixídio (Melo 1422); Portulaca frieseana Poelln. 8. Hábito; 9-11. Folhas; 12. Pixídio (Eiten 9333). 
5, amarelas, brancas ou creme; lâmina obcordada 5-7 x 2-3,5 mm, ápice emarginado; estames 10-15; filetes 1-3 mm compr.; anteras 0,5-1 mm compr; estilete 2-4,5 $\mathrm{mm}$ compr.; ramos estigmáticos 4-8, 1-1,5 mm compr. Pixídio 3,5-5 mm compr.; séssil, opérculo hemisférico 1-2 $\mathrm{mm}$ alt. Sementes $15-25$ por fruto, negras, opaca, 0,4-0,6 mm.

Material selecionado. BRASIL: Bahia: Jacobina, 17/I/1997, fl. fr. Arbo et al. 7408 (CEPEC). Ceará: Fortaleza, 18/II/2002, fl. fr., Souza et al. 28707 (ESA). Goiás: Paraíso, 24/III/1968, fl. fr., Irwin et al. 21736 (UEC). Minas Gerais: Grão Mogol, 31/I/1991, fl. fr., Taylor et al. 1515 (BHCB). Pará: Tucuri, 28/I/1980, fl. fr., Lisboa et al. 1219 (IAN). Paraíba: Puxinana, 19/XI/2001, fl. fr., Heringer et al. 2350 (HEPH). Pernambuco: Arcoverde, 18/I/1994, fl. fr., Miranda 1207 (SP). Piauí: São Raimundo, 07/II/1986, fl. fr., Laure 2827 (RB). Rio de Janeiro: Iatipuaçú, 09/ IX/1982, fl. fr., Andreata et al. 535 (RUSU). Roraima: Boa Vista, 01/V/1979, fl. fr., Rodrigues 752 (IAN).

Esta espécie é caracterizada por apresentar hábito ereto, pouco comum em Portulaca, com caules variando entre 20 e $80 \mathrm{~cm}$ de altura. $\mathrm{O}$ caule é bastante ramificado desde a base, apresentando cor verde ou avermelhado, neste último caso quando encontrado em ambientes áridos da caatinga. As folhas são lineares e pouco suculentas, com um pecíolo evidente de cerca de $2 \mathrm{~mm}$ compr. e bem diferenciado pela cor castanha. Além disto, é possível observar uma nervura central bem saliente na face abaxial, da base do pecíolo até mais ou menos cerca de $4 \mathrm{~mm}$ acima, nunca chegando até o meio da lâmina foliar.

Alguns autores como Rohrbach (1872) sugerem uma possível relação entre Portulaca elatior e Portulaca grandiflora. Embora estas espécies possuam semelhanças em relação à forma das folhas, as diferenças são marcantes, pois Portulaca elatior é uma planta ereta, com flores menores (5-7 $\mathrm{mm}$ ), enquanto Portulaca grandiflora tem hábito prostrado e flores muito desenvolvidas (10-15 mm).

3. Portulaca frieseana Poelln., Fedde Rep. 48: 117. 1940. Tipo: Brasil, Mato Grosso, Santa Ana da Chapada, 06/X/1902, Malme, Pl. Itin. Regnelliani II 1446 (Holótipo: S, n.v.)

Fig. 8 -12

Erva com caule prostrado, ramos com 4-8 cm compr., verde, pouco ramificado, sistema subterrâneo com raiz tuberosa obovóide na parte superior e afilada na parte inferior, tricomas axilares 5-10 mm compr., multisseriados, circundando todo o nó, abundantes, lanosos, castanhos. Folhas com pecíolo 0,5 - 1,5 mm compr., achatado; limbo 10-25 x 0,5-1 mm, linear-lanceolado, achatado, nervura central não evidente; base atenuada; ápice agudo a acuminado; margem inteira sem bordo esbranquiçado; glabras; folhas involucrais 4-5 por inflorescência, 10-15 x 1-1,5 mm, linear-lanceolada; base atenuada; ápice agudo a acuminado; margem inteira sem bordo esbranquiçado; glabras. Inflorescência 3-5 flores, com uma flor abrindo de cada vez. Flores sésseis com 15$20 \mathrm{~mm}$ de diâmetro; sépalas 5-10 x 3-6 mm, glabras; dorso côncavo; ápices agudos a mucronados; pétalas 5, magentas; lâmina obcordada 10-12 x 10-11,5 mm, ápice emarginado; estames 12-25; filetes 1,5-3 mm compr.; anteras 0,8-1 mm compr.; estilete 5-8 mm compr.; ramos estigmáticos 3-5, ca. $2 \mathrm{~mm}$ compr. Pixídio séssil, 1,5-2,5 mm compr., opérculo sub-hemisférico ca. $1 \mathrm{~mm}$ alt. Sementes $15-30$ por fruto, negras, opacas, $0,5-0,7 \mathrm{~mm}$.

Material selecionado: BRASIL: Goiás: Jataí, 25/ IX/1978, fl. Eiten et al. 9333 (UEC, SP). Mato Grosso: Santa Ana da Chapada, 02/XI/2002, fl. Robert 682 (BM). São Paulo: Altinópolis, 10/XI/1994, Ferreira-Neto et al. 94 (HRCB).

Portulaca frieseana foi descrita por Poellnitz (1940) e o nome foi uma homenagem ao Prof. R. E. Fries do Museu de Estolcomo, local onde está depositado o material-tipo da espécie.

A espécie é facilmente reconhecível no herbário, se o espécime portar a raiz tuberosa obovóide na porção superior e afilada na porção inferior. Provavelmente tal estrutura representa uma adaptação à sobrevivência da espécie no cerrado. As plantas são pequenas e prostradas com ramos de no máximo $10 \mathrm{~cm}$ de comprimento, porém com flores bastante desenvolvidas chegando a medir cerca de $2,5 \mathrm{~cm}$ de diâmetro. Por conta desta característica floral e hábito prostrado, é muito confundida com Portulaca grandiflora, diferindo pela densidade de tricomas no caule, morfologia da folha e número de estigmas.

4. Portulaca grandiflora Hooker, Bot. Mag. 56 tab. 2885. 1829. Tipo: Argentina, Mendoza, entre o Rio Saladillo e a base das montanhas próximas de Mendoza, s.d., Gillies s.n. (Holótipo E!, Isótipo K foto!).

Fig. 13-16

Erva com caule semi-prostrado a prostrado, ramos 10$15 \mathrm{~cm}$ compr., verdes, pouco ramificados, raiz principal tuberosa e alongada, tricomas axilares ca. 1,5 $\mathrm{mm}$ compr., multisseriados, interaxilares, inconspícuos, lanosos, esbranquiçados. Folhas com pecíolo 1,5-2 mm, cilíndrico; limbo 10-15 x 0,5-1 mm, linear-lanceolado, globoso, nervura central evidente, base atenuada; ápice agudo a acuminado; margem inteira sem bordo esbranquiçado; glabras; persistentes; folhas involucrais 3-6 por inflorescência, 10-15 x 0,5-1 $\mathrm{mm}$, linear-lanceoladas, ápice agudo a acuminado; margem inteira sem bordo esbranquiçado; glabras. Inflorescência 3-5 flores, com uma flor abrindo de cada vez. Flores sésseis com 2-5 cm de diâmetro; sépalas 1,5-2,5 mm compr., glabras, dorso côncavo, ápice mucronado; pétalas 5, púrpuras; lâmina obcordada 5-8 x 2-5 cm, ápice emarginado ; estames 15-20, filetes 1,5-2 mm compr.; anteras 1-1,5 mm compr.; estilete 2-4 mm compr.; ramos estigmáticos 3-6, ca. 1,5 mm compr. Pixídio 4-6 mm compr., pedicelo ca. 0,3 mm compr. opérculo hemisférico 1-2 mm alt. Sementes 20-30 por fruto, negras, 
opacas, 0,5-0,7 mm, células hexagonais, faces lateral e dorsal semelhantes, superfície papilada, papilas arredondadas.

Material selecionado: BRASIL: Bahia: Irará, 02/ II/.2004, fl. fr., Oliveira 400 (HUEFS). Goiás: Serranópolis, 17/XII/1994, fl. fr., Nóbrega 178 (HEPH). Mato Grosso do Sul: Corumbá, 08/XII/1993, fl. fr., Cervi et al. 4204 (UPCB). Mato Grosso: Poconé, 28/XI/1991, fl. fr., Schessi 2470 (CH). Paraná: Icaraíma, 20/IV/1968, fl. fr., Hatschbach et al. 19069 (MBM). São Paulo: Rio Claro, 31/VIII/1999, fl. fr., Rodrigues 45 (HRCB).

Portulaca grandiflora é uma espécie que possui pouca variação morfológica, sendo caracterizada principalmente pelas flores de $2-5 \mathrm{~cm}$ de diâmetro e pelas folhas lineares. Alguns espécimes de Portulaca grandiflora em diversos herbários estão erroneamente identificados como Portulaca werdermannii, provavelmente por ambas apresentarem flores grandes e de cor magenta. Porém, as diferenças entre estas espécies estão principalmente na morfologia do sistema subterrâneo, sendo muito mais desenvolvido e espessado em Portulaca werdermannii, e nas folhas que em Portulaca werdermannii possuem margem inteira e um acúmen esbranquiçado no material seco.

5. Portulaca halimoides L., Sp. pl. .2:639. 1762. Tipo: Jamaica. Voy Jamaica 1:2. 1707. fig.2 (Lectótipo BM! Epitipo aqui designado: Jamaica, s.n., s.col. BM!)

Fig. 17-20

Erva com caule semi-prostrado a prostrado, ramos 5-20 $\mathrm{cm}$ compr. verde, muito ramificado desde a base, tricomas axilares 6-8 mm compr., multisseriados, circundando todo o nó, muito abundantes, lanosos, esbranquiçados. Folhas com pecíolo 0,3-0,8 mm, cilíndrico; limbo 4-8 x 1-1,5 mm, linear a oblongo, cilíndrico, nervura central evidente; base arredondada; ápice obtuso a arredondado; margem inteira com pequeno bordo esbranquiçado; glabras, persistentes, podendo algumas vezes serem caducas; folhas involucrais 4-8 por inflorescência, 4-8 x 0,5-1 mm, lineares a oblongas; base arredondada; ápices obtusos a arredondados, margem inteira com pequeno bordo esbranquiçado; glabras. Inflorescência 2-6 flores, com uma flor abrindo de cada vez. Flores pediceladas com diâmetro de 4-8 $\mathrm{mm}$; sépalas 2-3 mm compr., glabras, dorso côncavo, ápices agudos; pétalas 4-5, brancas, amarelas ou rosas; lâmina obcordada 2-4 x 1-1,5 mm, ápice emarginado; estames 6-12; filetes 1,5-2 mm compr.; anteras 0,05-0,1 mm compr.; estilete 1-3 mm compr.; ramos estigmáticos 3-5, 1-1,5 mm compr. Pixídio 2-3 mm compr., pedicelado, pedicelo 1,5-2 mm compr., opérculo cônico, 1-1,5 mm alt. Sementes 8-15 por fruto, negras, opacas, $0,4-0,5 \mathrm{~mm}$.

Material selecionado: BRASIL: Acre: Rio Branco, 25/ IX/1951, fl.fr., Black 51-13737 (IAN). Amapá: Porto Platon, 16/IX/1961, fl. fr., Pires et al. 50971 (IAN). Bahia: Canudos, V/2003, fl. fr., Oliveira, et al. 198 (HUEFS). Ceará: Quixadá, II/1936, fl. fr., Drouet 2425 (F). Espírito Santo:
Guarapari, 14/XII/1979, fl. fr., Krieger s.n. (CESJ 40086). Goiás: Presidente Kennedy, 31/I/1980, fl. fr., Plowan et al. 8204 (F). Minas Gerais: Caeté, 11/I/1996, fl. fr., Souza et al. 10089 (ESA). Pará: Tucuruí, 28/I/1980, fl. fr., E. Oliveira 1206 (IAN). Paraíba: São João do Cariri, 15/V/1987, fl. fr., Felix et al. 3309 (JPB, K). Pernambuco: Recife, VIII/1934, fl. fr. Ramalho 10 (RB). Piauí: Floriano, 04/III/2005, fl. fr., Miranda et al. 5025 (HUEFS). Rio de Janeiro: Restinga Itapeba, 19/X/1980, fl. fr., Ribeiro 98 (GUA). Rio Grande do Sul: Caçapava do Sul, 30/V/1976, fl. fr., Porto et al. 2209 (ICN). Roraima: Boa Vista, 01/V/1979, fl. fr., Rodrigues et al. 775 (IAN)

Portulaca halimoides é caracterizada por possuir o caule bastante ramificado desde a base, principalmente em plantas que ocorrem em áreas de restinga ou próximo $\mathrm{a}$ áreas mais úmidas. $\mathrm{O}$ estudo de grande número de espécimes herborizados desta espécie e a análise das plantas na natureza permitiu concluir que as plantas que ocorrem no litoral apresentam geralmente maior número de ramos e folhas mais caducifólia, enquanto as plantas do interior, principalmente das caatingas são menos ramificados. Apesar de ocorrer tal variação a espécie é bem caracterizada pela presença de flores pediceladas e cápsula com pedicelo desenvolvido $(1-1,5 \mathrm{~mm})$, característica muito rara no gênero. $O$ pedicelo desenvolvido no fruto já foi referido por Linnaeus (1762) e ao longo da história taxonômica da espécie, vários táxons têm sido sinonimizados tendo como base a existência deste caráter. Além do pedicelo desenvolvido, a espécie é facilmente reconhecível por apresentar redução no número de pétalas, geralmente quatro, de estames entre 6-12 e no tamanho das sementes que geralmente atingem apenas 0,5 mm de comprimento.

6. Portulaca hatschbachii Legr. An. Mus. Hist. Nat. Montevideo 7: 105.1962. Tipo: Brasil, Paraná, Guarapuava, Rio Coutinho, 21. X.1960, Hatschbach 7518 (Holótipo MBM!).

Fig. 21-24

Erva com caule semi-prostrado, ramos 5-15 cm compr., verde, pouco ramificado, raiz tuberosa e alongada, tricomas axilares ca. $10 \mathrm{~mm}$ compr., multisseriados, circundando todo o nó, conspícuo e denso, lanosos, castanhos. Folhas com pecíolo 0,8-1 mm, cilíndrico; limbo 6-12 x 0,5-1 mm, oblanceolado, globoso, nervura central não evidente; ápice acuminado a agudo; margem inteira sem bordo esbranquiçado; glabras; persistentes; folhas involucrais 4-8 por inflorescência, 6-12 x 0,5-1 mm, oblanceoladas; base arredondada; ápices acuminados a agudos; glabras. Inflorescência 2-6 flores, abrindo uma flor de cada vez. Flores sésseis, com ca. de $15 \mathrm{~mm}$ de diâmetro; sépalas 2-4 mm compr., glabras, dorso côncavo, ápices agudos; pétalas 5, purpúreas; lâmina obcordada, 4-8 mm; ápices emarginados; estames 15-20; filetes 2-4 mm compr.; anteras $0,8-1 \mathrm{~mm}$ compr.; estilete 4-5 mm compr., ramos estigmáticos 3-6, ca. 1,5 mm compr. 


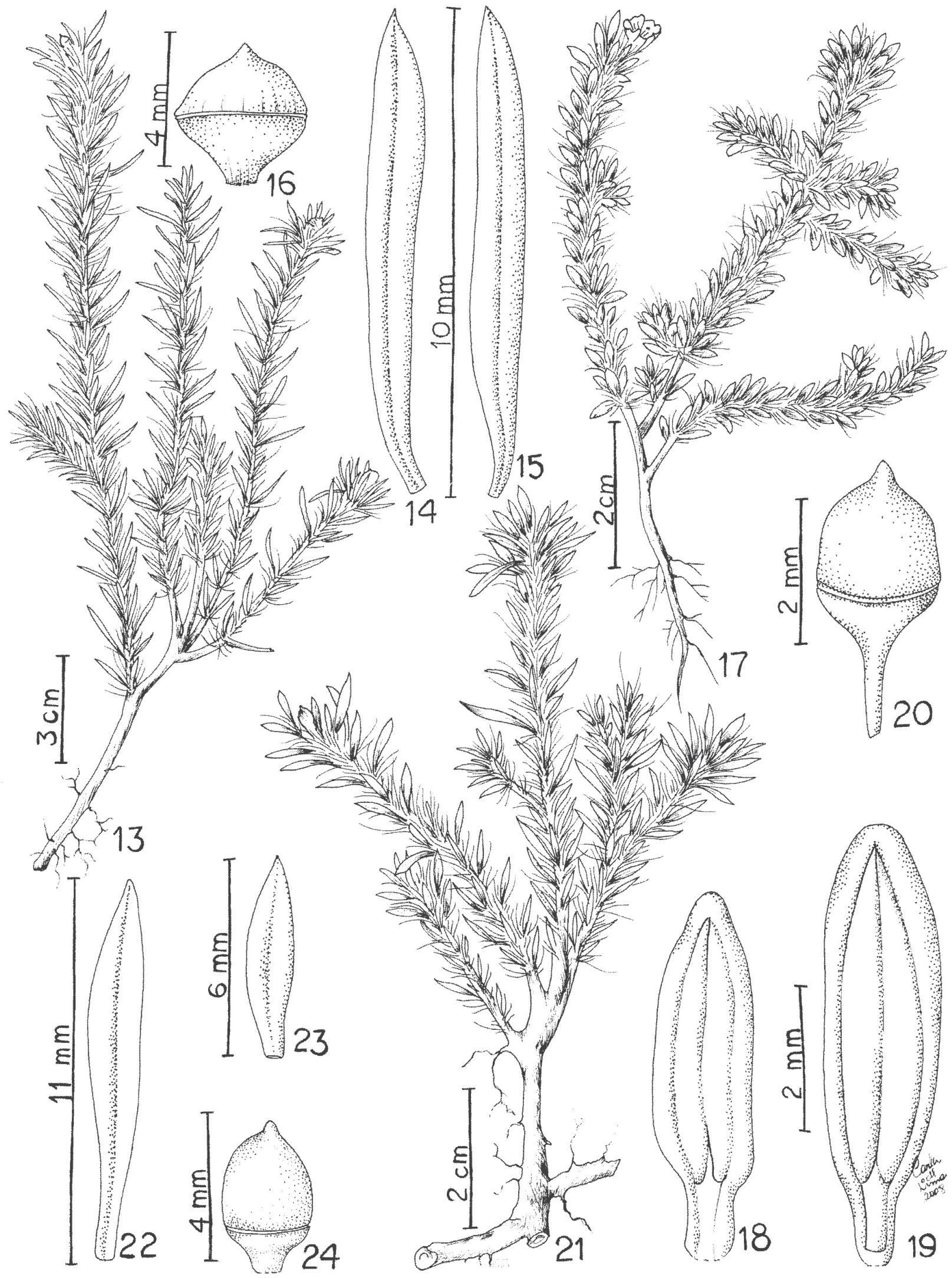

Figuras 13-24. Portulaca grandiflora Hook. 13. Hábito; 14-15. Folhas; 16. Pixídio (Oliveira 400); Portulaca halimoides L. 17. Hábito; 18-19. Folhas; 20. Pixídio (Harley 3275); Portulaca hatschbachii Legr. 21. Hábito; 22-23. Folhas; 24. Pixídio (Hatschbach 15175). 
Pixídio subsséssil, 4-6 mm compr., pedicelo ca. 0,2 mm, opérculo cônico 1-2 mm alt. Sementes $15-25$ por fruto, negras, opacas, $0,5-0,8 \mathrm{~mm}$.

Material selecionado. BRASIL: Paraná: Campo Mourão, 19/II/1962, fr. Hatschbach 8754 (MBM). Cantagalo, 14/XII/1992, fl.fr., Cervi et al. 3876 (MBM). Guarapuava, 29/XI/1988, fl.fr., Hatschbach \& O. S. Ribas 52545 (MBM, R). Londrina, 19/IX/1970, fr., Hatschbach 24866 (MBM, HRCB). Turvo, 13/IV/2002, fl.fr., Silva \& C. B. Poliquesi 3615 (MBM).

Legrand (1962) descreveu Portulaca hatschbachii apresentando como principais características diferenciais a cápsula sub-hemisférica, séssil e as sementes de cor cinza claro. O autor destaca que há semelhança entre a espécie descrita e Portulaca elatior.

Os materiais examinados mostram que a espécie é bem caracterizada pela presença de sistema subterrâneo muito desenvolvido em relação ao tamanho da planta, pela cor castanha dos tricomas, pelas pétalas magenta e pelas folhas que apresentam uma coloração quase negra quando herborizadas.

Embora Legrand (1962) tenha referido semelhança desta espécie com Portulaca elatior, isso não foi observado e as mesmas diferem pelo hábito, cor das pétalas e especialmente coloração das folhas depois de herborizadas.

7. Portulaca hirsutissima Camb. in Saint Hilaire Fl. bras. mer. 2: 191, t. 114. 1829. Tipo: Brasil, Minas Gerais, Nossa Senhora da Penha, s.d., Laruotte s.n. (Holótipo P!) Fig. 25-27

Erva com caule prostrado ou raramente ereto, ramos 10-40 cm compr., verdes, pouco ramificados, tricomas axilares 10-12 mm compr., multisseriados, circundando todo o nó, abundantes, lanosos, esbranquiçados. Folhas sésseis; limbo 5-15 x 1-2,5 mm, oblongo-linear, face adaxial plana e face abaxial convexa, sem nervura central evidente; base arredondada; ápice agudo a acuminado, margem inteira, face abaxial e adaxial do limbo e margem com tricomas curtos, glandulares unicelulares e tectores filamentosos, sendo geralmente caducos nas folhas mais velhas; folhas involucrais 5-10 por inflorescência, 5-15 x 1-2,5 mm, oblongo-lineares; base arredondada; ápices agudos a acuminados, margem inteira com tricomas curtos unicelulares. Inflorescência com 1-3 flores, abrindo uma de cada vez. Flores sésseis; sépalas 5-7 mm compr., com tricomas curtos unicelulares na margem e na face inferior, dorso côncavo, ápices agudos; pétalas 5, amarelas ou magentas; lâmina obcordada 12-15 x 10-12 mm, ápice emarginado; estames 15-40; filetes 3-5 mm compr.; anteras ca. $1 \mathrm{~mm}$ compr.; estilete $2-4,5 \mathrm{~mm}$ compr.; ramos estigmáticos, 4-7, 1-2 mm compr. Pixídio séssil, 2-4 mm compr., opérculo cônico 1-2 mm alt. Sementes 10-15 por fruto, negras, opacas, 0,5-0,6 $\mathrm{mm}$.

Material selecionado: BRASIL: Bahia: Rio de Contas, 25/IX/2003, fl.fr., Oliveira et al. 238 (HUEFS). Espírito Santo: Santa Tereza, 15/VII/2000, fl.fr., Fraga et al. 642
(MBML). Goiás: Alto Paraíso de Goiás, 06/XII/1997, fl.fr., Munhoz et al. 606 (HEPH). Minas Gerais: Diamantina, 28/IX/2003, fl.fr., Oliveira et al. 242 (HUEFS). Paraíba: João Pessoa, 15/IX/1954, fl.fr., Andrade-Lima 5009 (F). Rio de Janeiro: Recreio dos Bandeirantes, 22/VI/1960, fl.fr., Strang 182 (GUA).

Portulaca hirsutissima é facilmente reconhecível por apresentar tricomas glandulares unicelulares e tectores filamentosos, principalmente na face abaxial e margem das folhas. Segundo Legrand (1962) nas Américas apenas Portulaca hirsutissima e Portulaca confertifolia Haum. da Argentina apresentam tricomas nos limbos foliares, característica que as aproxima das espécies africanas. Segundo esse autor, as duas espécies também apresentam em comum a abundante pilosidade axilar, face adaxial da folha plana, estiletes alargados na porção distal e estigmas curtos. Porém as diferenças principais seriam os tipos de tricomas foliares e as cores das flores: em Portulaca hirsutissima o tricoma da folha seria tector e as flores amarelas, enquanto em Portulaca confertifolia os tricomas seriam glandulares e as pétalas purpúreas. Nas espécies estudadas do Brasil, os dois tipos de tricomas foram encontrados em Portulaca hirsutissima. Legrand (1962) citou Portulaca hirsutissima como sendo exclusiva do Brasil, ocorrendo da Bahia até Minas Gerais e Rio de Janeiro.

A espécie foi sempre referida como tendo apenas pétalas amarelas, Rohrbach (1872) já cita a espécie para a Bahia através do material coletado por Blanchet 1894, e Zappi (1995) referiu Portulaca hirsutissima como a única espécie do gênero no Pico das Almas, Bahia. Porém, após o exame de diversos materiais ao longo da distribuição geográfica, foi observado que Portulaca hirsutissima tem variação na cor da flor. Em Minas Gerais, Rio de Janeiro, Espírito Santo e Goiás todas as plantas coletadas apresentaram as flores amarelas. Na Bahia, ao longo da Chapada Diamantina, as flores são amarelas, principalmente na porção Sul e magenta para o Norte. No entanto, em alguns locais como Rio de Contas mais ao Sul e Vitória da Conquista a Sudeste e fora da Chapada Diamantina, as flores de cores amarelo e magenta ocorrem simpatricamente. Na Bahia, além de apresentar os dois tipos de flores, a espécie tem ocorrência em diferentes tipos de vegetação como Campos Rupestres, Caatingas, Cerrados e Dunas. Geralmente as plantas de regiões mais secas como a área da Capitinga em Lençóis, apresentam menor porte e tamanho reduzido das pétalas e fruto, enquanto que plantas de regiões mais úmidas ou próximas à beira de alagadiços, como a população coletada em Rio de Contas próximo ao rio Brumado apresentou estruturas foliares e florais mais desenvolvidas, além de serem mais ramificadas.

Em campo, e mesmo no material de herbário, Portulaca hirsutissima de flor magenta pode ser confundida com Portulaca werdermanni, endêmica da Bahia, pela ocorrência de folhas cilíndricas, tricomas axilares brancos e abundantes. Porém a principal diferença entre elas é a presença de tricomas nas folhas de Portulaca hirsutissima. 
8. Portulaca minensis Legr., Com. Bot. Mus. Hist. Nat. Montevideo 2 (27):3, 2f. 1953. Tipo: Minas Gerais, Ouro Preto ca. 1200m, s.d., Williams 8121 (Holótipo: GH, Isótipo MVM!)

Fig.28-31

Erva $20-25 \mathrm{~cm}$ alt., caule ereto, lignificado, marrom escuro, pouco ramificado, tricomas axilares $10-12 \mathrm{~mm}$ compr., circundando todo o nó, abundantes, com aspecto escarioso e de cor castanho-escura (escamas). Folhas sésseis; limbo 10-12 x 1-2 mm, oblongo-lanceolado, subgloboso, nervura central não evidente, base arredondada; ápice agudo a acuminado; margem inteira sem bordo esbranquiçado; glabras; persistentes; folhas involucrais 7-10 por inflorescência, 8-10 x 1-2 mm, oblongo-lanceoladas; base arredondada; ápice agudo a acuminado; glabras. Inflorescência 2-4 flores, com uma ou duas flores abrindo de cada vez. Flores sésseis; sépalas 5-7 mm compr., glabras, dorso côncavo, ápice agudo; pétalas amarelas; lâmina obcordada, 10-15 x 6-8 mm, ápice mucronado; estames 10-20, filetes 4-5 mm compr., anteras $0,5-1,0 \mathrm{~mm}$ compr.; estilete $4-8 \mathrm{~mm}$ compr.; ramos estigmáticos 5-7, $2 \mathrm{~mm}$ compr. Pixídio séssil, 2-3 mm compr., opérculo cônico, ca. $1 \mathrm{~mm}$ alt. Sementes 8-12 por fruto, negras, opacas, 0,3-0,5 mm.

Material selecionado. BRASIL: Minas Gerais: Mato Verde, 24/IX/2003, fl.fr., Oliveira et al. 241 (HUEFS). Monte Azul, 06/XI/2002, fl. fr., Araújo et al 54 (ESA, HUEFS).

Portulaca minensis foi descrita por Legrand (1962), que citou apenas o material-tipo coletado na região de Ouro Preto-MG. O autor refere que a espécie é próxima a Portulaca hirsutissima diferenciando-se pela ausência de tricomas nas folhas.

Portulaca minensis é uma espécie facilmente reconhecível no campo e no herbário pelo hábito ereto e caule bem escuro e lignificado, portando na axila das folhas escamas castanhas de aspecto crespo. Apesar da facilidade de identificação, todo o material conhecido da espécie se restringe ao material-tipo e duas coletas recentes feitas durante o desenvolvimento deste trabalho, em área distante cerca de $600 \mathrm{Km}$ da localidade tipo referida. Diante desta situação pode-se inferir que provavelmente esta espécie trata-se de um táxon endêmico para esta região. Em Mato Verde foi encontrada uma população com poucas plantas ocorrendo em campo rupestre com solos muito pedregosos.

9. Portulaca mucronata Link., Enum. Hort. Berol.2:2. 1822.

Tipo: s. loc., s.col., s.d., cultivado no Jardim Botânico de Berlim, de semente proveniente do Jardim Botânico de Viena. $(\dagger)$. Neótipo (aqui designado): Brasil, Bahia, Rio de Contas, Fazenda Fiúza, A. Oliveira et al. 239, 23/09/2003 (HUEFS!, SPF!, K!).

Fig. 32-35

Erva $10-25 \mathrm{~cm}$ alt., caule ereto, verde ou vermelho, pouco ramificado, tricomas axilares 4-6 $\mathrm{mm}$ compr., multisseriados, circundando todo o nó, pouco abundantes, lanosos, esbranquiçados. Folhas pecioladas, pecíolo 3-5 mm, limbo 15-20 x 4-8 mm, oblongo-lanceolado, plano, nervura central evidente; base arredondada; ápice agudo; margem inteira sem bordo esbranquiçado; glabras; algumas vezes caducas; folhas involucrais 4-8 por inflorescência, 15-20 x 4-8 mm, lanceoladas; base arredondada; ápice agudo; margem inteira sem bordo esbranquiçado; glabras. Inflorescência 2-5 flores. Flores sésseis; sépalas 6-8 x 4-6 mm, glabras, dorso côncavo, ápices agudos; pétalas amarelas, rosas ou alaranjadas; lâmina obcordada 6-12 x 7-10 mm, ápices emarginados; estames 20-30, filetes 2-3 mm compr., anteras 0,8-1 mm compr.; estilete 2,5-5 mm compr., ramos estigmáticos 5-7, ca. $2 \mathrm{~mm}$ compr. Pixídio séssil, 4-8 mm compr., opérculo hemisférico 2-3 mm alt. Sementes 15-35 por fruto, cinza plúmbeas, brilhantes, $0,6-0,8 \mathrm{~mm}$.

Material selecionado: BRASIL: Bahia: Morro do Chapéu, 22/IV/2001, fl.fr., Melo et al. 3446 (HUEFS). Espírito Santo: Vila Velha, 14/I/1964, fl. fr., Pereira et al. 8294 (LP). Maranhão: Imperatriz, 29/II/1980, fr., Plowman et al. 9358 (F). Mato Grosso: Poconé, 08/XI/2002, fl. fr., Melo 149 (BHCB). Mato Grosso do Sul: Bela Vista, 17/III/1985, fl. fr., Hatschbach 49172 (MBM). Minas Gerais: Diamantina, 14/III/1999, fl. fr., Souza et al. 22223 (ESA). Pará: Belterra, 22/X/1962, fl. fr., Oliveira 2312 (IAN). Paraná: Candói, 17/XI/1998, fl. fr., Hatschbach et al. 68785 (MBM). Rio de Janeiro: Rio de Janeiro, 1907, fr., Regnell-II 621 (P). Rio Grande do Sul: Santo Amaro, 10/XII/1996, fl. fr., Carneiro 491 (ICN). Santa Catarina: Laguna, 02/II/1987, fr., Guarauba 131 (HAS). São Paulo: Itirapina, 04/I/1995, fl. fr., Barreto et al. 3450 (ESA).

Portulaca mucronata é uma espécie que apresenta hábito ereto, com caules que podem chegar até $30 \mathrm{~cm}$ de altura, raízes espessadas e pouca pilosidade na axila das folhas. Indivíduos coletados em ambientes semi-ruderais, apresentam porte mais baixo e caule fino. Outra característica importante da espécie é a semente sem ornamentação. Portulaca mucronata tem sua área de distribuição na América do Sul, incluindo Venezuela, Brasil, Paraguai, Argentina e Uruguai.

10. Portulaca oleracea L., Sp. pl.: 445.1753. Tipo: América

Tropical, s.col., s.d., s.n.

Fig. 36-38

Erva com caule geralmente prostrado, ramos $15-30 \mathrm{~cm}$ compr., verdes ou vermelhos, podendo ter ramificação dicotômica, tricomas axilares 1-2 mm compr., multisseriados com cabeça capitada, interaxilares, inconspícuos, lanosos, esbranquiçados. Folhas sésseis a subsésseis, pecíolo 0-2 $\mathrm{mm}$,; limbo 10-25 x 5-10 mm, oblanceolado a espatulado, plano, nervura central evidente; base atenuada; ápice arredondado a obtuso; margem inteira sem bordo esbranquiçado; glabras; folhas involucrais 4-8 por inflorescência, 10-20 x 5-10 mm, oblanceoladas a espatuladas; base arredondada; ápice arredondado; margem inteira sem bordo esbranquiçado; glabras. Inflorescência com 2-6 flores. Flores sésseis, bo- 


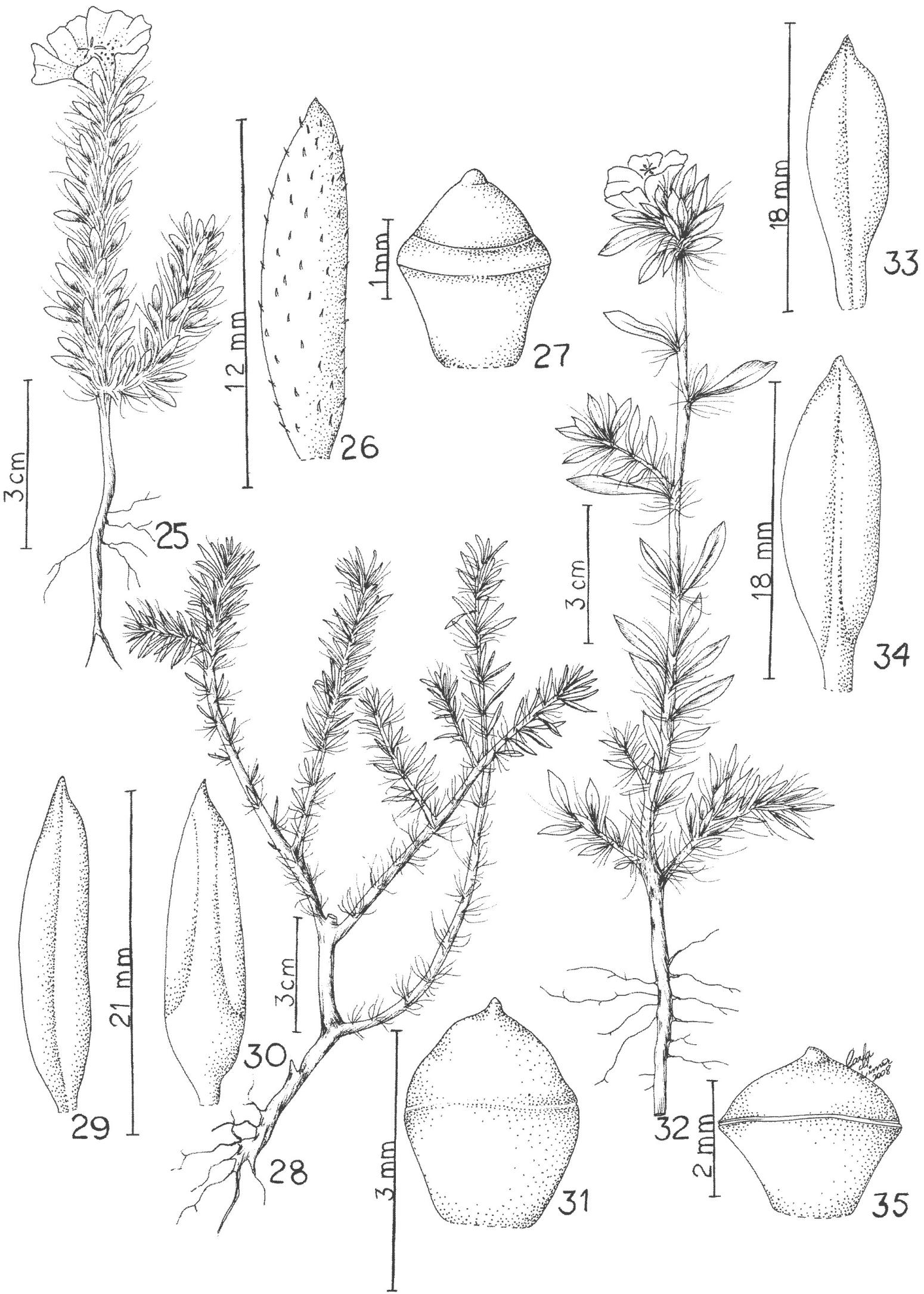

Figuras 25-35. Portulaca hirsutissima Camb. 25. Hábito; 26. Folha; 27. Pixídio (Oliveira 238); Portulaca minensis Legr. 28. Hábito; 29-30. Folhas; 31. Pixídio (Oliveira 241); Portulaca mucronata Link. 32. Hábito; 33-34. Folhas; 35. Pixídio (Harley 16818). 
tões florais achatados lateralmente; sépalas 4-6 mm compr., dorso carenado (carena aliforme), ápice agudo a acuminado; pétalas amarelas, brancas ou rosa; lâmina obcordada, 2-4 x 1,5-2 mm; estames 8-15, filetes 1-1,5 mm compr., anteras 0,3-0,5 mm compr.; estilete 1-1,5 mm compr., ramos estigmáticos 5-7, ca. 1,5 mm compr. Pixídio séssil, 4-8 mm compr., sem ala membranácea, opérculo cônico 2-3 mm alt. Sementes 20-30 por fruto, negras, opacas, $0,5-0,8 \mathrm{~mm}$.

Material selecionado: BRASIL: Amazonas: Manaus, 17/VII/1992, fl. fr., Nee 43014 (K). Bahia: Feira de Santana, 12/XII/1998, fl. fr., Oliveira 41 (HUEFS). Goiás: Piranhas, 22/VI/1996, fr., Irwin et al. 17588 (F). Mato Grosso: Barra do Garça, 01/XII/1969, fl. fr., Eiten \& L. T. Eiten 9661-C (K). Pará: Santarém, II/1950, fr., Spruce 912 -2 (K). Paraná: Curitiba, 28/XII/1913, fr., Dusen 14323 (F). Pernambuco: Fernando de Noronha, 09/V/1968, fr., Lima 5393 (F). Piauí: Uruçuí., 02/VII/1962, fr., Eiten et al. 4894 (K). Rio Grande do Norte: Currais Novos, 26/III/1972, fl. fr., Pickersgill et al. 72391 (K). Rio Grande do Sul: Porto Alegre, 11/V/1986, fl. fr., Hagelund 15990 (HAS). Roraima: Rio Laje, 21/ III/1971, fr., Prance et al. 11164 (K). Santa Catarina: Florianópolis, 13/II/1981, fl. fr., Heros 76 (HAS). São Paulo: São Paulo, 25/III/1961, fr., Eiten 2747 (K).

Portulaca oleracea é caracterizada principalmente pela presença de sépalas carenadas no botão floral, visível mesmo a olho nu (Figura 7 G). Rohrbach (1872) citou que tal característica separa a espécie de todas as outras do gênero. Outros autores como Teixeira (1959), Legrand (1962, 1978), Vianna et al. (1965) e Ford (1986) também confirmam a importância desta característica para o reconhecimento da espécie. O exame de material do Brasil permitiu observar que esta característica é imprescindível para a identificação da espécie, principalmente em material de herbário, cujas flores já não mais existem, além disto, esta característica permite a distinção entre esta espécie e Portulaca umbraticola, que é uma espécie muito próxima, mas que apresenta como característica diagnóstica uma ala membranácea ao redor do fruto.

Os tricomas axilares em Portulaca oleracea são pouco evidentes e alguns autores chegam a citar que os mesmos são inexistentes (Mattos, 1961; Vianna et al., 1965). No entanto, uma análise mais detalhada da região nodal do caule, permitiu observar a presença dos tricomas axilares que são pequenos e em número reduzido.

Portulaca oleracea tem o hábito completamente prostrado em ambientes muito ensolarados, e em ambientes com pouca luminosidade, estas plantas vão apresentar um hábito mais ereto, situação esta confirmada por Lorenzzi (1982). As plantas que crescem na caatinga são muito mais ramificadas do que plantas que ocorrem, por exemplo, em áreas de bordas de mata.

11. Portulaca pilosa L., Sp. Pl. 2: 445. 1753. Tipo: Lectótipo Herb. Linn. $n^{\circ}$ 625.2.

Fig. 39-42
Erva com caule geralmente prostrado, ramos $5-15 \mathrm{~cm}$ compr., verdes, muito ramificado, tricomas axilares ca. $4 \mathrm{~mm}$ compr., multisseriados, interaxilares, conspícuos, lanosos, esbranquiçados. Folhas com pecíolo 1,5-2 mm, cilíndrico; limbo 12-24 x 1-2 mm, linear-lanceolado, subglobosos, nervura central não evidente; base atenuada; ápice agudo; margem inteira sem bordo esbranquiçado; glabras; persistentes; folhas involucrais 5-10 por inflorescência, 15-20 x 1-2 mm, linear-lanceolada; base arredondada; ápice agudo; margem inteira sem bordo esbranquiçado; glabras. Inflorescência 3-7 flores, cada uma abrindo de uma vez. Flores sésseis com 0,4-0,8 cm de diâmetro; sépalas 5-7 $\mathrm{mm}$ compr., glabra, dorso côncavo, ápices agudos; pétalas 5, purpúreas; lâmina obcordada 4-8 mm, ápice emarginado; estames 15-20; filetes 2-3 mm compr., anteras $0,8-1 \mathrm{~mm}$ compr.; estilete 1,5-3 mm compr., ramos estigmáticos 4-5, 1,5-2,0 mm compr. Pixídio 3-5 mm compr., pedicelado, pedicelo 0,5 mm, opérculo cônico 1-2 mm alt. Sementes $10-15$ por fruto, negras, opacas, $0,5-0,7 \mathrm{~mm}$.

Material selecionado: BRASIL: Amazônia: São Gabriel, VIII/1852, fr., Spruce 2256 (BM). Mato Grosso: 1891, fr., Moore 1052 (BM). Mato Grosso do Sul: Corumbá, 12/V/1990, fl.fr., Amaral et al. s.n. (HUEFS 76823). Pará: Santarém, 1857, fr., Spruce 912/ 912-A (K).

Portulaca pilosa foi descrita por Linnaeus (1753) que não referiu qualquer espécime como parte do material original. Nesta obra o autor reconheceu apenas duas espécies em Portulaca: Portulaca oleracea e P. pilosa. Aparentemente, o critério utilizado para o reconhecimento das mesmas foi a presença de tricomas axilares evidentes em Portulaca pilosa e não evidente em Portulaca oleracea.

A espécie é caracterizada por apresentar tricomas axilares conspícuos, interaxilares e folhas lineares. Apesar de alguns autores relacionarem a mesma com Portulaca elatior, as diferenças estão principalmente no hábito prostrado e flores purpúreas em Portulaca pilosa.

12. Portulaca umbraticola Kunth in H.B.K., Nov. Gen. Sp. 6: 58.1823. Tipo: Colômbia-entre Cumana e Bordones. Humboldt 1225 (Holótipo P!)

Fig. 43-45

Ervas $15-30 \mathrm{~cm}$ alt., caule semi-prostrado a ereto, verde, muito ramificado, tricomas axilares ca. 1,5 mm compr., multisseriados, circundando todo o nó, inconspícuos, lanosos, esbranquiçados. Folhas com pecíolo 1-2 mm, cilíndrico; limbo 20-35 x 10-15 mm, oblanceolado a espatulado, plano, com nervura central evidente até a região próxima ao ápice e nervuras secundárias menores e inconspícuas; base atenuada; ápice arredondado a obtuso; margem inteira sem bordo esbranquiçado, mas com coloração avermelhada; glabras; persistentes; folhas involucrais 2-4 por inflorescência, 15-30 x 10-15 mm, oblanceoladas a espatuladas; base arredondada; ápice arredondado a obtuso podendo chegar algumas vezes a agudo; margem inteira sem bordo esbranquiçado; glabras. 


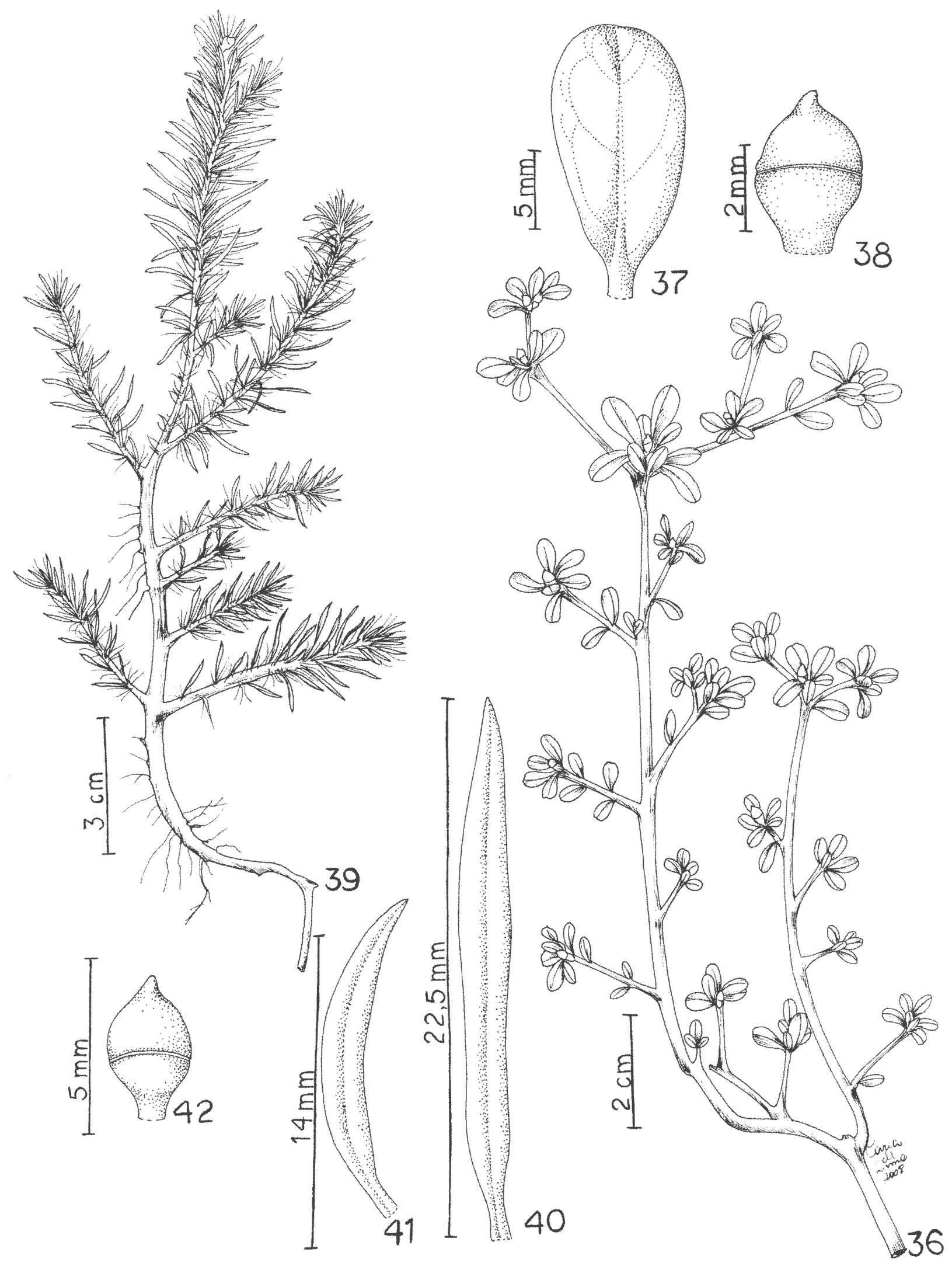

Figuras 36-42. Portulaca oleracea L. 36. Hábito; 37. Folha; 38. Pixídio (Carvalho 2761); Portulaca pilosa L. 39. Hábito; 40-41. Folhas; 42. Pixídio (Bastos 04). 
Inflorescência 3-5 flores, algumas vezes com duas flores abrindo ao mesmo tempo. Flores sésseis; sépalas 5-8 mm compr., glabras, ápices agudos; pétalas brancas, amarelas ou rosas; lâmina obcordada 8-15 x 2-4 mm, ápices emarginados; estames 15-25; filetes 3-5 mm compr.; anteras 1-1,5 mm compr.; estilete 2-6 mm compr.; ramos estigmáticos 5-8, 1,5$2 \mathrm{~mm}$ compr. Pixídio $2-4 \mathrm{~mm}$ compr., pedicelo ca. $0,5 \mathrm{~mm}$, opérculo hemisférico 1,5-2 $\mathrm{mm}$ alt., parte basal do pixídio com margem formada por expansão alada membranácea, 0,5-1 mm alt. Sementes 18-30 por fruto, cinza plúmbeas, brilhantes, 0,6-0,8 $\mathrm{mm}$.

Material selecionado: BRASIL: Bahia: Feira de Santana, 24/IX/1998, fl. fr., Oliveira 39 (HUEFS). Ceará: Crato, 27/II/1972, fr. Pickersgill et al. 221(K). Maranhão : São Luís, 14/IX/1959, fr., Fróes 34770 (IAN). Mato Grosso: Corumbá, 22/VII/1977, fl. fr., Gibbs et al. 5395 (F). Minas Gerais: Monte Azul, 28/I/1991, fl. fr., Taylor et al. 1462 (K). Paraíba: Areia, s.d., fl. fr., Moraes 983 (IAN). Rio Grande do Norte: Currais Novos, 26/ III/1972, fr., Pickersgill et al.391 (K).

Portulaca umbraticola foi descrita por Kunth (1823) com base no material Bonpland 1225, depositado em Paris. A espécie foi caracterizada por apresentar caule ramoso, folhas lanceoladas, tricomas axilares quase nulos e flores de cor rosa. Após a publicação de Kunth, vários táxons com características semelhantes de hábito, folha e principalmente fruto foram descritos para a Argentina e Venezuela. Legrand (1962) citou estes nomes como sinônimos de Portulaca umbraticola .

Portulaca umbraticola é uma espécie bem caracterizada pela presença de uma ala membranácea ao redor do fruto, que chega, algumas vezes, a cobrir o opérculo, não tendo sido observado em qualquer outra espécie dentro do gênero no Brasil. A cor das pétalas em Portulaca umbraticola pode variar desde amarelo, até branco, rosa, púrpura ou tons de alaranjado. A variação nas cores das flores já havia sido registrada por Legrand (1962), que relacionou tal variação com a distribuição geográfica, sendo que as cores rosa ou alaranjada são mais comuns do Sudoeste dos Estados Unidos até o México; púrpura na Argentina e amarelo nas Antilhas e Guianas. Exemplares do Brasil apresentaram coloração que varia do rosa ao amarelo, mas a maioria das plantas possui flores amarelas. Os estiletes e estigmas também podem variar de cor, sendo amarelos quando as pétalas são amarelas ou rosa quando as pétalas são de cor rosa. Segundo Legrand (1962), a espécie é muito confundida com Portulaca oleracea por apresentar hábito muito ramificado. Porém, uma análise mais detalhada permitiu observar características que podem perfeitamente distinguir os dois táxons, como a morfologia do botão floral e do fruto e o tamanho maior das flores em Portulaca umbraticola.

13. Portulaca werdermannii Poelln. Fedde Rep.33: 164.1933. Tipo: Brasil, Bahia: Morro do Chapéu, IV. 1932, Werdermann 3374 (Holótipo B foto!)

Fig. 46-48
Erva, com caule prostrado, ramos $15-20 \mathrm{~cm}$ compr., verdes, ramificados, raiz principal bastante espessada, tricomas axilares ca. 15-20 mm comp., multisseriados, circundando todo o nó, muito abundantes, lanosos, esbranquiçados. Folhas sésseis a subsésseis, pecíolo $0,5-0,6 \mathrm{~mm}$, cilíndrico; limbo 10-20 x 2-5 mm, oblongo-lanceolado, subcilíndrico, face abaxial plana com pequena fenda central e face adaxial convexa, nervura central não evidente; base arredondada; ápice mucronado; margem inteira com um acúmen esbranquiçado no material seco; glabras; persistentes; folhas involucrais 5-10 por inflorescência, 10-18 x 2-4 mm, oblongas; base arredondada; ápice mucronado, margem inteira com um acúmen esbranquiçado no material seco; glabras. Inflorescência 2-4 flores, com uma flor abrindo de cada vez. Flores sésseis com diâmtero de 2-3 cm; sépalas $8-10 \mathrm{~mm}$ compr., glabro, dorso côncavo, ápices acuminados; pétalas 5 , magentas; lâmina obcordada 1,5-2 x 1-2 cm, ápice emarginado; estames 20-35; filetes 6-9 mm compr.; anteras 1,5-2 mm compr.; estilete 2-4 mm compr.; ramos estigmáticos 5-7, 1,5- 2 mm compr. Pixídio 3-5 mm compr., séssil, opérculo hemisférico 1-2 mm. Sementes 15-20 por fruto, negras, opacas, $0,5-0,7 \mathrm{~mm}$.

Material selecionado: BRASIL: Bahia: Delfino, 03/ IV/2002, fl.fr., Oliveira et al. 111 (HUEFS).

Portulaca werdermannii é caracterizada por apresentar folhas com ápice mucronado e partes florais bastante desenvolvidas, com corolas que chegam a atingir até $4,5 \mathrm{~cm}$ de diâmetro. As folhas, quando herborizadas, apresentam as margens esbranquiçadas e translúcidas, que se prolongam até o acúmen apical. A espécie também se caracteriza pela presença de um sistema subterrâneo bastante desenvolvido e espessado que no material seco forma uma espécie de casca que é retirada com facilidade. Apesar destas características marcantes, algumas vezes no campo a espécie pode ser confundida com Portulaca hirsutissima, por ambas terem hábito similar e folhas cilíndricas. Porém, fazendo-se uma análise detalhada das plantas é possível perceber a presença de tricomas nas folhas de Portulaca hirsutissima, além do tamanho menor da flor e das sementes. Uma outra espécie com a qual Portulaca werdermannii pode ser confundida à primeira vista é Portulaca grandiflora devido ao grande tamanho das flores. Porém o hábito e as características vegetativas distinguem facilmente os dois táxons.

A espécie só foi coletada até o presente em campos rupestres no estado da Bahia na porção central (Ipupiara, Anadarái e Mucugê) e norte da Chapada Diamantina nos municípios de Morro do Chapéu (localidade tipo), Umburanas, Jacobina, Seabra, Campo Formoso, Delfino e Minas do Mimoso.

\section{Lista de Exsicatas}

Amaral, J. J. et al.: s.n. HUEFS 76823 (11); Andreata, R. et al.: 535 (2); Araujo, A. O. et al.: 54 (8); Arbo. M. M. et al.: 7408 (2); Barreto, K. D. et al.: 3450 (9); Bertolotto, I. M. et al.: 554 (1); Black, G. A.: 51-13737 (5); Carneiro, 

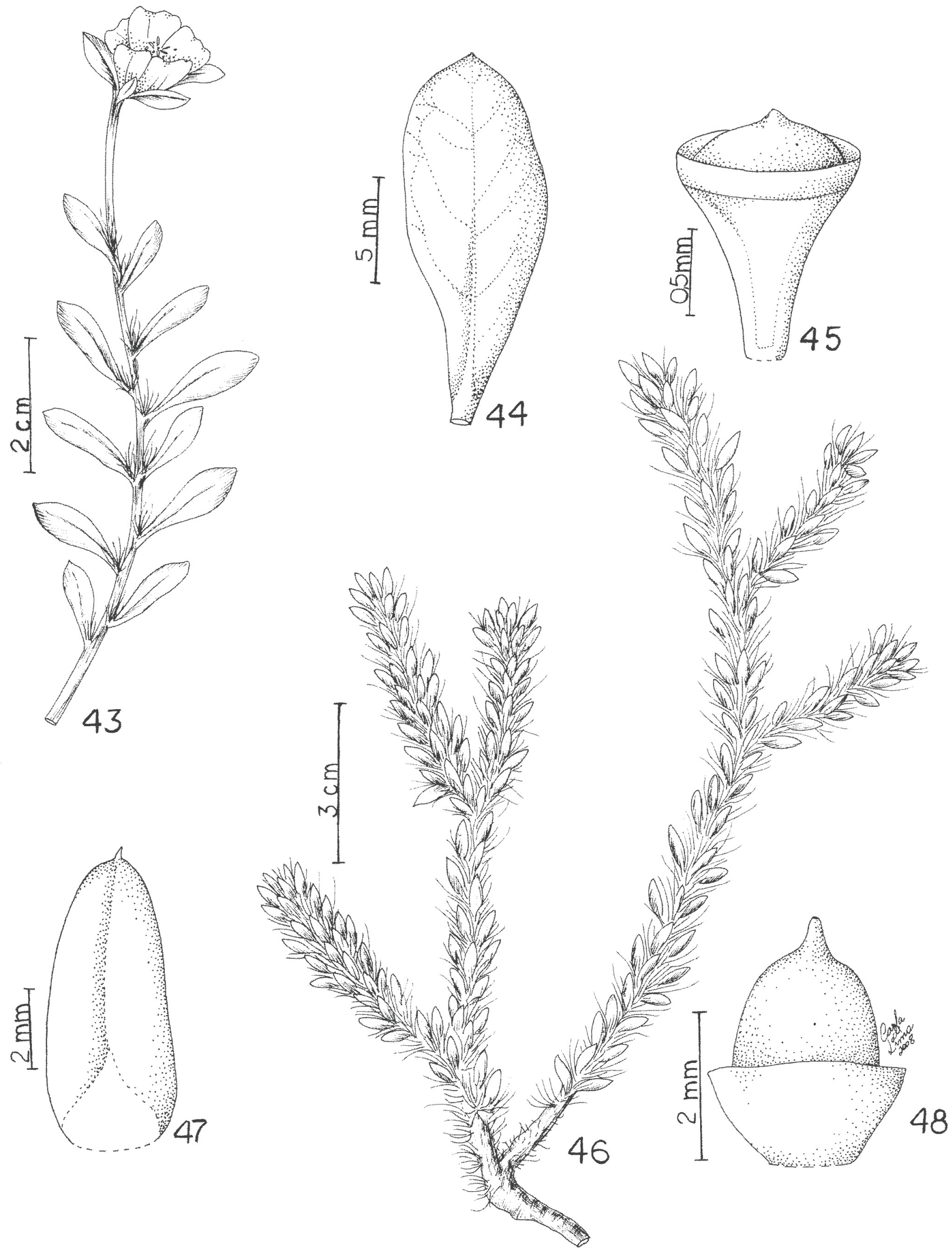

Figuras 43-48. Portulaca umbraticola Kunth. 43. Hábito; 44. Folha; 45. Pixídio (Oliveira 111); Portulaca werdermannii Poelln. 46. Hábito; 47. Folha; 48. Pixídio (Oliveira 39). 
A. M.: 491 (9); Casari, M. B. et al.: 908 (1); Cervi, A. C. et al:: 4204 (4), 3876 (6), 52545 (6), 24866 (6); Drouet, F.: 2425 (5); Dusen, P.: 14323 (10); Eiten. G. et al.: 9333 (3), 9661 (10), 4894 (10), 2747 (10); Felix, L. P. et al.: 3309 (5); Ferreira-Neto, W. M. et al.: 94 (3); Fraga, C. N. et al:: 642 (7); Fróes, R. L.: 34770 (12); Gibbs, P. E. et al.: 5395 (12); Guarauba, J.: 131 (9); Hagelund, K.: 15990 (10); Hatschbach, G. et al.: 19069 (4), 8754 (6), 49172 (9), 68785 (9); Heringer, A. et al.: 2350 (2); Heros: 76 (10); Irwin, H. S. et al.: 21736 (2), 17588 (10); Klein, R. M.: 6502 (1), 6770 (1); Krieger, L. : s.n. CESJ 40086 (5); Laure, E.: 2827 (2); Lima, D. A.: 5009 (7), 5393 (10); Lisboa , P. et al.: 1219 (2); Magenta, M. A. G. et al.: 222 (1); Melo, E. et al.: 3446 (9); Melo, P. H. A.: 149 (9); Miranda, A. M.: 1207 (2), 5025 (5); Moraes, J. C.: 983 (12); Munhoz, C. et al.: 606 (7); Nee, M.: 43014 (10); Nóbrega, M. G.: 178 (4); Oliveira, A. et al.: 400 (4), 198 (5), 238 (7), 242 (7), 241 (8), 41 (10), 39 (12), 111 (13); Oliveira, E.: 1206 (5), 2312 (9); Pereira, E. et al.: 8294 (9); Pickersgill, B. et al.: 72931 (10), 221 (12), 391 (12); Pires, J. M. et al.: 50971 (5); Plowan, T. et al.: 8204 (5), 9358 (9); Porto, M. L. et al.: 2209 (5); Prance, G. T. et al.: 11164 (10); Ramalho, L.: 10 (5); Regnell: 621 (9); Ribeiro, R.: 98 (5); Robert, A.: 682 (3); Rodrigues, I. A.: 752 (2), 775 (5); Rodrigues, M. I.: 45 (4); Schesse. M.: 2480 (1), 2470 (4); Schwarz, J. G.: 7253 (1); Silva, J. M. et al:: 3615 (6); Souza, V. C. et al.: 28707 (2), 10089 (5), 22223 (9); Spencer, M.: 1052 (11); Spruce: 912 (10), 2256 (11), 912-A (11); Strang, H. E.: 182 (7); Strudwick, J. J. et al.: 4132 (1); Taylor, N. et al.: 1515 (2), 1462 (12).

\section{Agradecimentos}

Ao Programa de Taxonomia (CNPq/CAPES) pelo apoio financeiro. Às desenhistas Rosane Quintella pela confecção das pranchas e Carla Lima pelo acabamento final e cobertura a nanquim.

\section{Referências bibliográficas}

Applequist, W.L. \& Wallace, R.S. 2001. Phylogeny of the Portulacaceous Cohort Based on ndhF Sequence Data. Systematic Botany 26(2): 406-419.

Carolin, R.C. 1987. A Review of the family Portulacaceae. Australian Journal of Botany 35: 383-412.

Carolin, R.C. 1993. Portulacaceae. Pp. 544-555. In: K. Kubitzki, J.B. Rhower \& V. Bittrich (eds.) The Families and Genera of Vascular Plants. Flowering Plants -Dicotyledons (2), Berlin, Ed. Springer Verlag.
Coelho, A.A.O.P. \& Giulietti, A.M. 2006. Flora da Bahia: Portulacaceae. Sitientibus: Série Ciências Biológicas 6(3): 182-193.

Coelho, A. A.O.P.; Giulietti, A.M.; Harley, R.M. \& Yesilyurt, J.C. 2009. Synonymies and typifications in the Portulaca (Portulacaceae) of Brazil. Kew Bulletin 65:37-43

Eggli, U. \& Ford-Werntz, D. 2002. Illustrated Handbook of Succulent Plants- Dicotyledons. Portulacaceae. Pp. 370-432. New York, Ed. Springer.

Ford, D.I. 1986. Flora de Vera Cruz Vol. 51. Vera Cruz, Instituto Nacional de Investigaciones sobre Recursos Bióticos.

Geesink, R. 1969. An account of the genus Portulaca in Indo-Australia and the Pacific (Portulacaceae). Blumea 17: 275-307.

Holmgren, P.; Holmgren, N.H. \& Branett, L.C. 2006. Index Herbariorum (I). Internacional Association for Plants Taxonomyc. Kew, Royal Botanic Gardens.

Kunth, C.S.; Von Humboldt, F.A. \& Bonpland, A. 1823. Nova Genera et Species Plantarum. p. 70-75.

Legrand, C.D. 1953. Desmembracion del genero Portulaca. Comunicaciones Botanicas del Museo de Historia Natural de Montevideo 31(3):1-15.

Legrand, C.D. 1958. Desmembracion del genero Portulaca. Comunicaciones Botanicas del Museo de Historia Natural de Montevideo 34(3):1-17.

Legrand, C.D. 1962. Las Especies Americanas de Portulaca. Anales del Museo de Historia Natural de Montevideo 7(3): 9-147.

Legrand, C.D. \& Mattos, J.R. 1978. Portulacaceae do Rio Grande do Sul. Roessleria 2(1): 7-37.

Lima, D.M. \& Lima, A.M.B. 1968. Flora de Pernambuco: Portulacaceae. Sociedade Botânica do Brasil, XIX Congresso Nacional de BotânicaAnais, Fortaleza, p: 60-63.

Linnaeus, C. 1753. Species Plantarum. Stokholm. 560p.

Linnaeus, C. 1762. Species Plantarum 2. ed. Holmiae, Laurentii Salvii.

Lorenzi, H. 1982. Portulacaceae. Plantas Daninhas do Brasil. São Paulo, Instituto Plantarum de Estudos da Flora LTDA.

Mattos, N.F. 1961. Portulacaceae de São Joaquim. Sellowia 13: 133-136.

Mori, A.S.; Silva, L.A.M.; Lisboa, G. \& Coradin, L. 1989. Manual de herbário fanerogâmico. Ilhéus, Centro de Pesquisa do Cacau.

Poellnitz, V.P. 1940. Feedes Repertorium Specierum Novarum Regni Vegetablis 40: 117-118.

Prabhakar, M. \& Ramayya, N. 1975. Structure and development of trichomes in the family Portulacaceae. Form, structure and function in plants. Ed. Sarita Prakashan, Índia.

Rodrigues, M.I.A. \& Furlan, A. 2002. Flora Fanerogâmica do estado de São Paulo. Portulacaceae. São Paulo, Ed. Hucitec. p. 261-268.

Rohrbach, P. 1872. Portulacaceae. In: C.F.P. Martius e A.G. Eichler (eds.) Flora Brasiliensis 14 (2): 293-306, Munique, Lipsiae.

Teixeira, L. 1959. Portulacaceae da cidade do Rio de Janeiro. Rodriguesia 21,22 (33/34): 299-316.

Vianna, F. S.; Ormond, W. T. \& Dau, L. 1965. Flora Ecológica das Restingas do Sudeste do Brasil 2: 33p.

Willis, J. C. 1966. A dictionary of flowering plants and ferns. $7^{\mathrm{a}} \mathrm{ed}$. Cambridge, University Press.

Zappi, D. C. 1995. Portulacaceae. In: B.L. Stannard (ed.) Flora of the Pico das Almas - Chapada Diamantina - Bahia - Brazil. Kew, Royal Botanical Gardens. 